\title{
Ionome Changes in Xylella fastidiosa-Infected Nicotiana tabacum Correlate With Virulence and Discriminate Between Subspecies of Bacterial Isolates
}

\author{
J. E. Oliver, ${ }^{1}$ S. A. Sefick, ${ }^{2}$ J. K. Parker, ${ }^{1}$ T. Arnold, ${ }^{1}$ P. A. Cobine, ${ }^{2}$ and L. De La Fuente ${ }^{1}$ \\ ${ }^{1}$ Department of Entomology and Plant Pathology and ${ }^{2}$ Department of Biological Sciences, Auburn University, Auburn, AL \\ 36849, U.S.A.
}

Submitted 7 April 2014. Accepted 24 June 2014.

\begin{abstract}
Characterization of ionomes has been used to uncover the basis of nutrient utilization and environmental adaptation of plants. Here, ionomic profiles were used to understand the phenotypic response of a plant to infection by genetically diverse isolates of Xylella fastidiosa, a gram-negative, xylem-limited bacterial plant pathogen. In this study, $X$. fastidiosa isolates were used to infect a common model host (Nicotiana tabacum 'SR1'), and leaf and sap concentrations of eleven elements together with plant colonization and symptoms were assessed. Multivariate statistical analysis revealed that changes in the ionome were significantly correlated with symptom severity and bacterial populations in host petioles. Moreover, plant ionome modification by infection could be used to differentiate the $X$. fastidiosa subspecies with which the plant was infected. This report establishes host ionome modification as a phenotypic response to infection.
\end{abstract}

Characterization of the ionome, defined as the mineral nutrient and trace elements found in an organism (Lahner et al. 2003), has been used to identify functional plant genes involved in the transport of nutrients (Baxter and Dilkes 2012; Baxter et al. 2008, 2009; Chao et al. 2011; Munns et al. 2012) and understand plant adaptation to soil conditions (White et al. 2012) and water and salt stress (Sanchez et al. 2011; Sanchez-Rodriguez et al. 2010). Ionomic profiles have been shown to be a robust phenotype that is strongly dependent on the plant family (White et al. 2012). Studies on mineral element accumulation in specific plant tissues, in particular the leaf ionome (Baxter et al. 2008), have been used as an assessment of plant physiological status. Regarding disease development in plant and animal hosts, the influence of specific mineral elements is welldocumented (De La Fuente et al. in press; Hood and Skaar 2012; Fones and Preston 2013); however, the ionome has only been used in a few instances as a composite phenotypic char-

Nucleotide sequence data are available in the GenBank database under numbers KF445148-KF445154 and KF437626-KF437629

Corresponding author: L. De La Fuente Telephone: +1.334.844.2582; Fax: +1.315.844.1947; E-mail: lzd0005@auburn.edu

* The $\boldsymbol{e}$-Xtra logo stands for "electronic extra" and indicates that Figures 1 through 4 appear in color online.

(C) 2014 The American Phytopathological Society acter to assess the relationship of a pathogen with its plant host (Cobine et al. 2013; De La Fuente et al. 2013; Hood and Skaar 2012).

Xylella fastidiosa is a gram-negative, xylem-limited plant pathogenic bacterium that infects a variety of plant hosts including grape (Pierce's disease [PD]), almond (almond leaf scorch [ALS]), peach (phony peach disease [PPD]), citrus (citrus variegated chlorosis [CVC]) (Purcell and Hopkins 1996), and blueberry (bacterial leaf scorch [BLS]) (Chang et al. 2009). The symptoms of diseases caused by $X$. fastidiosa include leaf scorch (in PD, ALS, and BLS), chlorosis (in CVC), and shortened internodes and leaf darkening (in PPD). Though $X$. fastidiosa causes disease in a wide range of host plants, most $X$. fastidiosa isolates show host specificity and have been classified into four different subspecies. $X$. fastidiosa subsp. fastidiosa is isolated mostly from grape and almond, X. fastidiosa subsp. pauca is isolated from citrus and coffee, $X$. fastidiosa subsp. sandyi is isolated from oleander, and $X$. fastidiosa subsp. multiplex is isolated from diverse hosts such as elm, plum, weeds, and blueberry. A multilocus sequence typing approach has been used for classification of $X$. fastidiosa in subspecies (Scally et al. 2005; Nunney et al. 2012) and to study the evolutionary history and diversity of this bacterium (Nunney et al. 2010, 2013). In addition, phylogenetic analysis of multiple environmentally-mediated genes (MLSA-E) (Parker et al. 2012) that play a role in X. fastidiosahost interactions have also been used to explain the relationships within $X$. fastidiosa subspecies.

$X$. fastidiosa is generally understood to cause symptoms in host plants either by plugging xylem vessels and restricting the flow of water within the host via the formation of bacterial biofilm (Chatterjee et al. 2008), by the induction of tylose formation (Sun et al. 2013), or both. However, several studies have suggested that the response of the host to $X$. fastidiosa infection goes beyond a response to water stress alone, indicating $X$. fastidiosa symptoms involve an additional host component (Baccari and Lindow 2011; Carazzolle et al. 2011; Choat et al. 2009; Choi et al. 2013; Gambetta et al. 2007). Induced host responses to $X$. fastidiosa infection are known to include ethylene generation (Perez-Donoso et al. 2007), which causes symptoms similar to accelerated senescence (Choat et al. 2009; Queiroz-Voltan et al. 1998), tylose formation (Fritschi et al. 2008; Sun et al. 2013), and ionomic remodeling (De La Fuente et al. 2013). These observations, along with the fact that $X$. fastidiosa infection is asymptomatic in many plant species, has led to the suggestion that $X$. fastidiosa causes symp- 
toms by triggering an inappropriate host response (Choi et al. 2013). The mechanism by which $X$. fastidiosa triggers a plant host tolerance, resistance, or susceptibility response is still unknown. Based on $X$. fastidiosa-infected citrus transcriptome analysis, it has been suggested that $X$. fastidiosa is able to trigger a pathogen-associated molecular pattern-triggered immunity response as well as phytohormone rearrangements, which suggests direct recognition of $X$. fastidiosa by the plant host (Rodrigues et al. 2013). Though $X$. fastidiosa is surrounded by host xylem tissue, which is largely composed of dead cells, it has been suggested that grape plants may recognize $X$. fastidiosa invasion through the protoxylem (Choi et al. 2013).

Though $X$. fastidiosa was the first plant-pathogenic bacterium to have its full genome sequenced (Janse and Obradovic, 2010; Simpson et al. 2000; Van Sluys et al. 2003), relatively few $X$. fastidiosa isolates have been characterized, and only a small number of studies have looked at virulence variation among isolates (Daugherty et al. 2010; Francis et al. 2008; Lopes et al. 2010). Virulence comparisons among isolates

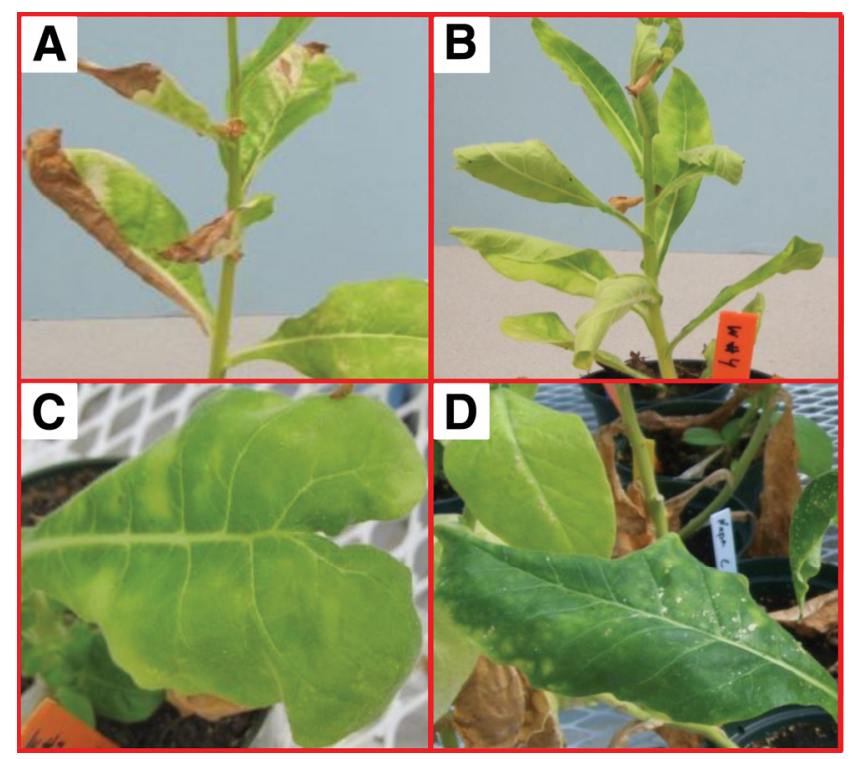

Fig. 1. Symptoms caused by Xylella fastidiosa infection of Nicotiana tabacum, including $\mathbf{A}$, leaf scorch, B, leaf cupping or curling, C, intraveinal chlorosis, and $\mathbf{D}$, leaf darkening and greening. from different subspecies can be difficult due to the limited host ranges of isolates. It remains unclear if $X$. fastidiosa host specificity is due to differences in host responses to isolates, differential expression of virulence factors in the hosts, or both. In alfalfa, in which $X$. fastidiosa infection induces stunting but not leaf scorch, the subspecies classification of $X$. fastidiosa isolates can drive perceptible differences in virulence (Daugherty et al. 2010; Lopes et al. 2010). In Arabidopsis thaliana, X. fastidiosa does not move systemically or cause symptoms (Rogers 2012), preventing the use of this model plant for virulence comparisons. However, in Nicotiana tabacum (tobacco), CVC strains of $X$. fastidiosa are capable of colonizing and causing leaf scorch symptoms (Alves et al. 2003; Lopes et al. 2000), and $X$. fastidiosa isolates from almond and grape showed differences in host colonization and symptomatology (Francis et al. 2008). In our prior work, N. tabacum was used to study mineral nutrient and trace element composition (namely, ionome) changes caused by $X$. fastidiosa Temecula- 1 upon infection of its plant host (De La Fuente et al. 2013). This work showed that $X$. fastidiosa infection alters the host leaf ionome and causes an increase in leaf calcium $(\mathrm{Ca})$ concentrations before the appearance of symptoms.

The goal of this study was to test whether the host ionome modifications caused by $X$. fastidiosa infection varied when genetically diverse isolates were inoculated in a common host. Nicotiana tabacum was inoculated with a collection of $X$. fastidiosa isolates to study the effects on the host leaf and sap ionome, colonization, and development of symptoms. A correlation was found between virulence and mineral element composition in host leaves and sap. Interestingly, the leaf and sap ionome changes during infection correlate with the subspecies classification of the isolates used to infect $N$. tabacum. This work shows that host ionome is a robust phenotype that is influenced by infection with a xylem-limited bacterium and suggests an intimate relationship of recognition between $X$. fastidiosa and plant hosts.

\section{RESULTS}

Xylella fastidiosa symptoms in tobacco vary by isolate.

Around 60 days postinoculation (dpi) with $X$. fastidiosa, tobacco plants began to show typical leaf-scorch symptoms (Fig. 1A) as well as a variety of other symptoms (Fig. 1; Table 1). These included a progressive, persistent curling or cupping of

Table 1. Bacterial colonization and symptoms caused by Xylella fastidiosa in tobacco

\begin{tabular}{|c|c|c|c|c|c|c|c|c|c|}
\hline \multirow[b]{2}{*}{ Isolates } & \multirow[b]{2}{*}{$\mathbf{R S I}^{\mathbf{a}}$} & \multicolumn{6}{|c|}{ Symptoms observed } & \multicolumn{2}{|c|}{ X. fastidiosa population } \\
\hline & & $\begin{array}{c}\text { Leaf } \\
\operatorname{scorch}^{b}\end{array}$ & $\begin{array}{l}\text { Leaf curling/ } \\
\text { cupping }\end{array}$ & $\begin{array}{c}\text { Intraveinal } \\
\text { chlorosis }^{b}\end{array}$ & $\begin{array}{c}\text { Vein } \\
\text { bleaching }\end{array}$ & $\begin{array}{c}\text { Leaf } \\
\text { darkening }\end{array}$ & $\begin{array}{c}\text { Reduced } \\
\text { height }^{\mathrm{d}}\end{array}$ & $\mathbf{n}^{\mathrm{e}}$ & Mean $\pm \mathbf{S E}^{\mathrm{f}}$ \\
\hline WM1-1 & 7 & $\mathrm{X}$ & $\mathrm{X}$ & $\mathrm{X}$ & $\mathrm{X}$ & $\mathrm{X}$ & $\mathrm{X}$ & 13 & $1.0 \times 10^{7} \pm 3.5 \times 10^{6}$ \\
\hline BB08-1 & 6 & \pm & $X$ & $\mathrm{X}$ & $\mathrm{X}$ & $\mathrm{X}$ & $\mathrm{X}$ & 15 & $1.3 \times 10^{6} \pm 5.6 \times 10^{5}$ \\
\hline GilBec625 & 5 & $\mathrm{X}$ & \pm & & \pm & $\mathrm{X}$ & $\mathrm{X}$ & 14 & $1.1 \times 10^{7} \pm 3.9 \times 10^{6}$ \\
\hline Napa-Silverado & 4 & \pm & & & $\mathrm{X}$ & $\mathrm{X}$ & $\mathrm{X}$ & 14 & $7.2 \times 10^{6} \pm 2.8 \times 10^{6}$ \\
\hline CCPM1 & 3.5 & & \pm & & $X$ & $X$ & $\mathrm{X}$ & 16 & $4.6 \times 10^{6} \pm 1.8 \times 10^{6}$ \\
\hline BBI64 & 3.5 & $\mathrm{X}$ & \pm & & & & $\mathrm{X}$ & 14 & $1.7 \times 10^{6} \pm 1.1 \times 10^{6}$ \\
\hline AlmaEm3 & 3 & \pm & $X$ & & $X$ & & & 16 & $8.9 \times 10^{5} \pm 6.3 \times 10^{5}$ \\
\hline Temecula- $1 *$ & 2.5 & \pm & \pm & & & & $\mathrm{X}$ & 9 & $1.4 \times 10^{6} \pm 9.4 \times 10^{5}$ \\
\hline King3 & 2 & & & & & $\mathrm{X}$ & $\mathrm{X}$ & 15 & $4.8 \times 10^{6} \pm 2.5 \times 10^{6}$ \\
\hline EB92-1 & 1.5 & & \pm & & & & $\mathrm{X}$ & 15 & $3.9 \times 10^{6} \pm 1.3 \times 10^{6}$ \\
\hline PD92-8 & 1 & & & & & & $\mathrm{X}$ & 14 & $7.5 \times 10^{6} \pm 2.4 \times 10^{6}$ \\
\hline Teme4 & 1 & & & & & & $\mathrm{X}$ & 14 & $8.9 \times 10^{6} \pm 4.0 \times 10^{6}$ \\
\hline ConnCreek & 0 & & & & & & & 11 & $4.0 \times 10^{3} \pm 2.2 \times 10^{3}$ \\
\hline
\end{tabular}

${ }^{\text {a }}$ RSI indicates the relative symptom incidence score calculated for each isolate.

b An "X" indicates symptom incidence $>50 \%$; " \pm " indicates 33 to $50 \%$ incidence.

c An "X" indicates symptom incidence $>33 \%$ and significant leaf chlorophyll ${ }_{\mathrm{A}+\mathrm{B}}$ increase versus buffer control treatment at $P<0.05$ ( $n=73$ to 106$)$.

d An " $X$ " indicates significant difference from buffer control treatment at $P<0.05$.

e Indicates the number of plants confirmed by qPCR to be infected by X. fastidiosa out of 16 plants inoculated for ionome analysis.

${ }^{\mathrm{f}}$ Bacterial population measured as the mean CFU per gram of petiole material \pm standard error of the mean. 

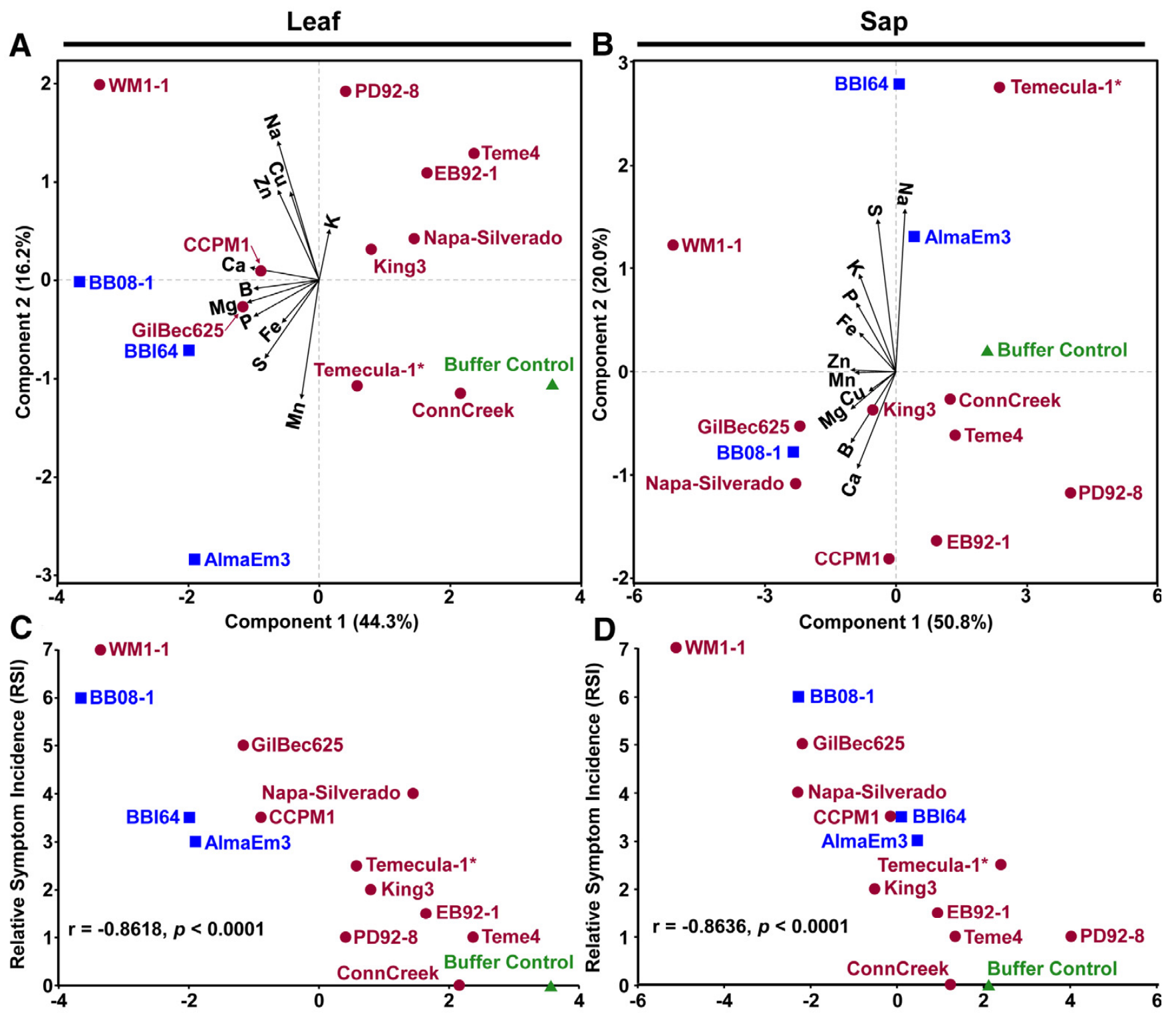
the leaf (Fig. 1B), chlorotic patches of the leaves especially noticeable in the intraveinal areas (Fig. 1C), a bleaching of the leaf veins (data not shown), a darkening of leaves to a deep green (Fig. 1D), and reduced heights (Table 1). Using the calculated relative symptom incidence (RSI) to compare isolate symptoms, isolate WM1-1 was relatively more aggressive than isolates (in order of RSI) BB08-1, GilBec625, Napa-Silverado, CCPM1 and BBI64, AlmaEm3, Temecula-1*, King3, EB92-1, Teme4 and PD92-8, and ConnCreek (Table 1).

\section{Bacterial colonization of the host petiole varies between $X$. fastidiosa subspecies.}

Bacterial populations were quantified in plant leaf material obtained from petioles in which quantities, in general, ranged between $10^{6}$ and $10^{7}$ colony-forming units (CFU) per gram (Table 1). Bacterial populations did not substantially differ by timepoint sampled; therefore, the data in Table 1 represents merged data from all timepoints and all experiments. In general, Xylella fastidiosa subsp. multiplex isolates in our study had approximately 10-fold lower populations compared with Xylella fastidiosa subsp. fastidiosa isolates, and as a whole, bacterial populations in $X$. fastidiosa subsp. multiplex were significantly lower than populations in $X$. fastidiosa subsp. fastidiosa $(P=0.0006)$, in agreement with previous results from tobacco (Francis et al. 2008) and alfalfa (Daugherty et al. 2010).

\section{Host ionomic changes caused by isolate infection.}

Leaf ionomes. Using mineral element concentrations determined by inductively coupled plasma with optical emission spectroscopy (ICP-OES), we applied our random effects model and used principal component analysis (PCA) to visualize the relationship among isolates due to differences between isolates' effects on the host leaf ionome ( $\mathrm{PCA}_{\text {leaf }}$; Fig. 2A). As depicted with eigenvectors for each mineral element in Figure $2 \mathrm{~A}$, the concentrations of $\mathrm{Mg}, \mathrm{Ca}, \mathrm{P}$, and $\mathrm{B}$ were correlated with one another along the $x$ axis, while other mineral elements, including $\mathrm{Na}, \mathrm{Mn}, \mathrm{Zn}$, and $\mathrm{Cu}$, were correlated along the $y$ axis. In this visualization of the ionomes, the $X$. fastidiosa subsp. multiplex isolates were found to group together in the lower left-hand quadrant (Fig. 2A). Further testing indicated that the mineral elements B $(P=0.0117)$, Ca $(P=$ 0.0903), $\mathrm{Mg}(P=0.0252), \mathrm{P}(P=0.0003)$, and $\mathrm{S}(P=0.0038)$ showed the most difference between leaves from plants infected with $X$. fastidiosa subsp. multiplex versus $X$. fastidiosa subsp. fastidiosa isolates. Significant changes in individual mineral elements in infected leaves relative to the buffer control were also observed, including significant $(P<0.05, n=9$ to 16 plants with 93 to 122 leaves per isolate) increases in $\mathrm{B}, \mathrm{Ca}, \mathrm{K}$, $\mathrm{Mg}, \mathrm{Na}, \mathrm{P}$, and $\mathrm{S}$ in the host leaves for some isolate treatments (Table 2). In total, six of the seven most aggressive isolates (RSI $\geq 3$, with the exception of Napa Silverado, RSI $=4$ ) caused significantly $(P<0.05)$ higher leaf concentrations of $\mathrm{B}$, $\mathrm{Ca}$, and $\mathrm{Mg}$, and all but CCPM1 caused a significantly $(P<$ $0.05)$ higher leaf concentration of $\mathrm{P}$. Moreover, $\mathrm{Ca}$ and $\mathrm{Mg}$ were only significantly $(P<0.05)$ affected by the six isolates considered to be the most virulent (highest RSI) among the isolates tested. Very few changes in leaf elemental composition were found after infection with less aggressive isolates $(\mathrm{RSI}<$ $3)$, and in particular, no significant changes $(P<0.05)$ in elemental concentrations were observed for the least aggressive isolates ConnCreek (RSI $=0)$ and Teme4 $(\mathrm{RSI}=1)$.

Sap ionomes. Host sap ionomes were also visualized via PCA ( $\mathrm{PCA}_{\text {sap }}$; Fig. 2B). The concentrations of mineral elements $\mathrm{Zn}$, $\mathrm{B}, \mathrm{Mg}, \mathrm{Mn}$, and $\mathrm{Ca}$ were correlated with one another along the $x$ axis, while other mineral elements including $\mathrm{Na}, \mathrm{S}$, and $\mathrm{K}$

Table 2. Relative changes in the concentrations of individual elements in leaves of tobacco plants infected with different Xylella fastidiosa isolates

\begin{tabular}{|c|c|c|c|c|c|c|c|c|c|c|c|c|}
\hline \multirow[b]{2}{*}{ Isolates } & & \multicolumn{11}{|c|}{ Leaf mineral element changes $(\%)^{a}$} \\
\hline & & B & $\mathbf{C a}$ & $\mathbf{C u}$ & $\mathbf{F e}$ & $\mathbf{K}$ & Mg & Mn & $\mathbf{N a}$ & $\mathbf{P}$ & $\mathbf{S}$ & $\mathbf{Z n}$ \\
\hline \multirow[t]{2}{*}{ WM1-1 } & Mean & 20.1 & 23.4 & 118.3 & 62.2 & 6.3 & 24.2 & 13.2 & 62.0 & 28.0 & 14.9 & 112.3 \\
\hline & $\mathrm{SE}^{\mathrm{b}}$ & 13.0 & 10.3 & 76.3 & 27.6 & 12.6 & 9.5 & 16.3 & 13.5 & 8.9 & 11.2 & 79.0 \\
\hline \multirow[t]{2}{*}{ BB08-1 } & Mean & 33.2 & 20.3 & 119.3 & 36.8 & 7.8 & 19.9 & 1.5 & 48.7 & 42.3 & 15.3 & 31.8 \\
\hline & $\mathrm{SE}$ & 11.1 & 9.4 & 35.6 & 30.5 & 9.3 & 8.7 & 12.2 & 18.6 & 9.6 & 12.9 & 18.1 \\
\hline \multirow[t]{2}{*}{ GilBec625 } & Mean & 21.8 & 15.4 & -0.7 & 42.4 & 34.4 & 15.5 & 14.7 & 48.3 & 18.2 & 13.5 & 10.1 \\
\hline & $\mathrm{SE}$ & 11.0 & 10.5 & 43.8 & 35.8 & 12.6 & 9.4 & 19.6 & 17.7 & 6.8 & 13.4 & 14.1 \\
\hline \multirow[t]{2}{*}{ Napa-Silverado } & Mean & 7.9 & 7.7 & 4.0 & -9.9 & 3.2 & 4.0 & -11.0 & 34.2 & 2.3 & -6.3 & 6.9 \\
\hline & $\mathrm{SE}$ & 10.4 & 7.5 & 43.1 & 9.8 & 12.1 & 7.0 & 12.2 & 13.6 & 5.4 & 11.1 & 20.6 \\
\hline \multirow[t]{2}{*}{ CCPM1 } & Mean & 21.5 & 16.4 & 76.1 & 44.0 & 9.4 & 14.5 & 10.0 & 46.8 & 10.5 & 1.3 & 0.7 \\
\hline & $\mathrm{SE}$ & 10.7 & 10.4 & 76.9 & 24.0 & 9.5 & 10.1 & 12.2 & 15.5 & 5.1 & 10.5 & 12.8 \\
\hline \multirow[t]{2}{*}{ BBI64 } & Mean & 28.0 & 19.1 & 45.1 & 111.4 & 1.6 & 20.8 & -2.0 & 33.6 & 35.3 & 17.6 & 1.1 \\
\hline & $\mathrm{SE}$ & 12.9 & 8.9 & 14.2 & 101.1 & 14.5 & 8.4 & 14.1 & 19.9 & 9.5 & 11.5 & 9.5 \\
\hline \multirow[t]{2}{*}{ AlmaEm3 } & Mean & 19.4 & 12.9 & -1.4 & 22.3 & 3.4 & 16.1 & 17.7 & 7.9 & 37.1 & 20.4 & 0.6 \\
\hline & $\mathrm{SE}$ & 9.2 & 8.3 & 36.5 & 24.4 & 8.0 & 8.4 & 10.6 & 10.1 & 9.0 & 8.9 & 10.6 \\
\hline \multirow[t]{2}{*}{ Temecula- $1 *$} & Mean & 20.2 & -1.8 & 23.6 & 128.8 & 38.8 & 6.0 & 16.6 & 21.0 & 7.6 & 11.8 & -7.3 \\
\hline & $\mathrm{SE}$ & 12.0 & 8.7 & 57.9 & 125.9 & 14.6 & 9.6 & 25.3 & 14.5 & 6.0 & 13.5 & 9.9 \\
\hline \multirow{2}{*}{ King3 } & Mean & 15.4 & 3.8 & 51.8 & -16.3 & 15.4 & 4.3 & 5.8 & 23.2 & 19.5 & 9.9 & 34.9 \\
\hline & SE & 11.2 & 7.6 & 21.5 & 9.2 & 11.8 & 6.1 & 13.6 & 12.5 & 6.4 & 9.8 & 36.5 \\
\hline \multirow[t]{2}{*}{ EB92-1 } & Mean & 14.7 & 3.6 & 11.7 & 0.1 & 28.8 & 5.9 & -2.9 & 46.1 & 13.7 & 6.8 & 23.0 \\
\hline & $\mathrm{SE}$ & 10.4 & 5.7 & 42.9 & 13.8 & 14.0 & 4.7 & 9.9 & 13.9 & 5.1 & 9.4 & 28.0 \\
\hline \multirow[t]{2}{*}{ PD92-8 } & Mean & 19.7 & 9.6 & 75.4 & 34.0 & 20.4 & 7.4 & -9.6 & 69.1 & 13.7 & 15.7 & 4.9 \\
\hline & $\mathrm{SE}$ & 6.9 & 7.2 & 31.1 & 27.2 & 13.3 & 6.9 & 8.3 & 22.4 & 7.0 & 12.1 & 12.6 \\
\hline \multirow[t]{2}{*}{ Teme4 } & Mean & 6.1 & 0.9 & 85.3 & -5.0 & 13.8 & -1.2 & -9.1 & 33.9 & 15.4 & -6.9 & -18.1 \\
\hline & $\mathrm{SE}$ & 11.4 & 10.1 & 70.2 & 19.4 & 14.1 & 7.8 & 13.9 & 14.2 & 8.4 & 9.3 & 10.1 \\
\hline \multirow[t]{3}{*}{ ConnCreek } & Mean & -0.4 & -10.2 & 89.3 & -6.0 & 10.2 & -4.3 & 8.7 & 11.5 & 16.2 & 6.4 & -14.5 \\
\hline & $\mathrm{SE}$ & 10.0 & 7.5 & 97.9 & 16.2 & 14.4 & 7.0 & 13.6 & 16.2 & 9.6 & 11.2 & 12.4 \\
\hline & & \multicolumn{11}{|c|}{ Leaf mineral element concentration } \\
\hline \multirow[t]{2}{*}{ Buffer control $^{\mathrm{c}}$} & Mean & 0.01 & 31.0 & 0.001 & 0.05 & 14.2 & 8.3 & 0.06 & 0.07 & 8.5 & 4.2 & 0.04 \\
\hline & SE & 0.001 & 2.6 & 0.0005 & 0.007 & 1.6 & 0.6 & 0.007 & 0.01 & 0.5 & 0.4 & 0.005 \\
\hline
\end{tabular}

a Bold indicates statistically significant $(P<0.05)$ percentage changes relative to the buffer control treatment.

b $\mathrm{SE}=$ standard error of the mean.

${ }^{c}$ Values shown as milligrams per gram of tissue. 
were correlated along the $y$ axis (Fig. 2B). Relative to the buffer control, significant $(P<0.05, n=3$ to 6 plants per isolate) increases in individual mineral elements, including $\mathrm{B}, \mathrm{P}$, and $\mathrm{Zn}$, were observed in the sap from plants inoculated with isolate WM1-1 (data not shown). No other changes were significant at $P<0.05$.

\section{Relationships between virulence traits and host ionomic changes.}

Symptom incidence is correlated with leaf and sap ionomes. Since $X$. fastidiosa isolates produced differential symptoms on host tobacco and differential effects on the host ionome, these differences were compared. Component 1 from the $\mathrm{PCA}_{\text {leaf }}$ plot (Fig. 2A) was significantly correlated $(r=-0.8618, P<$ 0.0001 ) with RSI for each isolate (Fig. 2C). Direct testing of individual elements indicated significant correlations (at $P<$ 0.05 ) between several host leaf elements and symptoms including $\mathrm{Ca}(r=0.9227, P<0.0001), \mathrm{Mg}(r=0.8887, P<$ $0.0001), \mathrm{B}(r=0.7351, P=0.0027), \mathrm{Zn}(r=0.6683, P=$ $0.0090), \mathrm{Na}(r=0.5908, P=0.0261), \mathrm{P}(r=0.5876, P=$ 0.0271). Component 1 from the PCA plot (Fig. 2B), based on host sap, was significantly correlated $(r=-0.8636, P<0.0001)$ with RSI for each isolate. Direct testing of individual elements indicated correlations between several host sap elements and symptoms including $\mathrm{B}(r=0.7557, p=0.0022), \mathrm{Ca}(r=$

\section{A}
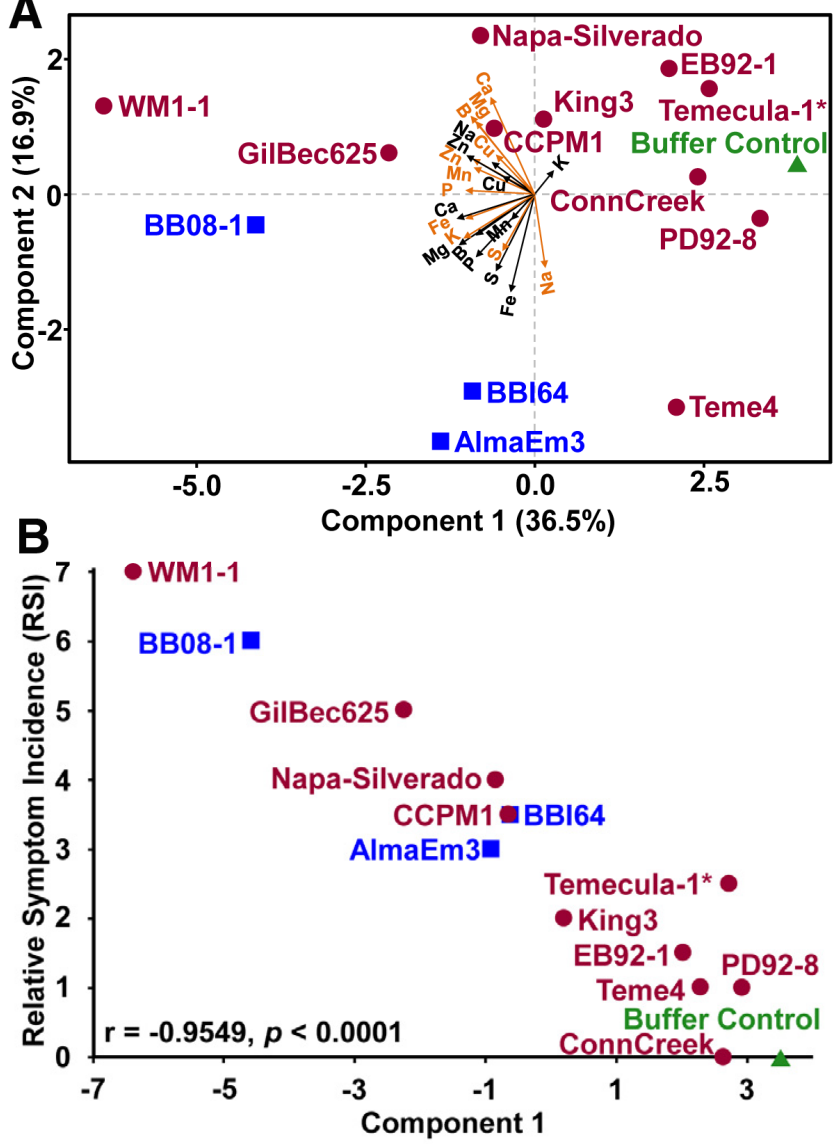

Fig. 3. Combined host leaf and sap ionome principal component analysis (PCA). A, Results are shown by isolate and $\mathbf{B}$, its relationship with symptom incidence. Shapes indicate whether the isolate mean depicted is that of the buffer control (triangle), Xylella fastidiosa subsp. fastidiosa (circle), or $X$. fastidiosa subsp. multiplex (square). A, Combined host leaf and sap ionome PCA results by isolate. The eigenvectors for each sap mineral element are shown in gray and each leaf mineral element is shown in black. $\mathbf{B}$, Correlation between Component 1 ( $x$ axis) from the combined leaf and sap ionome and the relative symptom incidence score for each isolate ( $y$ axis).
$0.4921, P=0.0739), \mathrm{Fe}(r=0.7514, P=0.0019), \mathrm{K}(r=$ $0.8342, P=0.0002), \operatorname{Mg}(r=0.6180, P<0.0185), \operatorname{Mn}(r=$ $0.6449, P=0.0128), \mathrm{P}(r=0.7368, P=0.0026), \mathrm{Zn}(r=$ $0.8181, P=0.0003)$. When leaf and sap ionomic effects were combined into a single PCA plot ( $\mathrm{PCA}_{\text {leaf } / \text { sap }}$; Fig. 3A), Component 1 showed a stronger correlation with symptoms than leaf or sap alone $(r=-0.9549, P<0.0001)$ (Fig. 3B).

Bacterial population is correlated with leaf but not sap ionome. Component 2 from the $\mathrm{PCA}_{\text {leaf }}$ plot (Fig. 2E) was significantly correlated $(r=0.7011, P=0.0052)$ with the bacterial population in the primary xylem of the petioles. Direct testing of individual elements indicated a significant correlation $(P<0.05)$ between host leaf $\mathrm{Na}$ and bacterial population $(r=$ 0.6997, $P=0.0053$ ). Neither Component 1 (data not shown) nor Component 2 (Fig. $2 \mathrm{~F}$ ) from the $\mathrm{PCA}_{\text {sap }}$ plot were significantly correlated with bacterial population. However, direct testing for individual host sap mineral elements did indicate that sap B $(r=0.6085, P=0.0209)$ and sap Ca $(r=0.5704, P=$ $0.0332)$ were significantly correlated with bacterial population in petioles. There was no significant relationship between symptoms and petiolar bacterial populations $(r=0.3825, P=$ $0.1771)$.

\section{Ionomic changes in the host discriminate between $X$. fastidiosa isolate subspecies.}

Due to the results from the $\mathrm{PCA}_{\text {leaf }}$ (Fig. 2A) and $\mathrm{PCA}_{\text {leaf /sap }}$ (Fig. 3A) bi-plots showing separation of ionomic effects by isolate subspecies, canonical discriminant analysis (CDA) was performed. Using either host leaf ionomic effects (Fig. 4A) or host sap ionomic effects (Fig. 4B), CDA was able to discriminate between $X$. fastidiosa subsp. fastidiosa and $X$. fastidiosa subsp. multiplex. Discriminant 1 described $100 \%$ of the differences between groups. The highest structural correlations for the host leaf ionome were found for the following mineral elements: $\mathrm{B}(r=-0.6738, P=0.0116), \mathrm{Ca}(r=-0.4891, P=$ $0.0899), \mathrm{Mg}(r=-0.6160, P=0.0250), \mathrm{P}(r=-0.8487, P=$ $0.0002), \mathrm{S}(r=-0.7411, P=0.0038)$. Also, for the host sap ionome (Fig. 4B), significant structural correlations of mineral elements were found for $\mathrm{Fe}(r=0.5692, P=0.0423)$ and $\mathrm{K}(r=$ $0.5984, P=0.0307)$.

The relationship between ionomic changes in the host and $X$. fastidiosa isolates at the subspecies level was confirmed by comparison of genetic distances among isolates with ionome differences. Controlling for virulence differences among isolates, a significant correlation $(r=0.3406, P=0.0079)$ was observed between a genetic distance matrix based on $X$. fastidiosa nucleotide sequences of nine environmentally-mediated genes (MLSA-E) (Parker et al. 2012) and a host leaf ionome distance matrix. No significant relationship was observed between isolate genetics and ionome differences at the within subspecies level $(P>0.05)$.

\section{DISCUSSION}

The modification of the plant host ionome by infection with a bacterial pathogen was established here as a meaningful phenotypic characterization of disease development that is correlated with pathogen virulence. Furthermore, it was shown that plant host ionome modifications can reflect the subspecies of the bacterial pathogen with which the plant is infected, highlighting the complexity of the plant host-pathogen relationship. The close correlation between the magnitude of ionome changes, symptoms, and isolate subspecies in the plant host $-X$. fastidiosa system suggests the possibility that one or more subspecies-specific signals may exist that induce a host response that works in combination with the plugging of the xylem conduits to induce disease. 
This research demonstrated that plant host ionomes were modified by infection with $X$. fastidiosa. However, ionome modifications were not uniform; on the contrary, they varied and were distinguishable among infections with 13 genetically distinct $X$. fastidiosa isolates showing different degrees of virulence. The correlation observed between host ionomic changes and the subspecies of the infecting isolate is indicated by the significant separation by PCA and CDA of plants infected with $X$. fastidiosa subsp. multiplex and $X$. fastidiosa subsp. fastidios $a$ isolates and is further supported by the significant relationship between host leaf ionome distance and genetic distance. There is limited genetic variability among the $X$. fastidiosa species (Van Sluys et al. 2003), and the genetic determinants of host specificity are almost entirely unknown. It has been suggested, however, that differences in gene regulation in response to environmental conditions, rather than the presence of particular virulence factor genes alone, play a major role in host adaptation of this organism, based on work with rpfF (Killiny and Almeida 2011). This gene encodes an enzyme responsible for the synthesis of diffusible signal factor, a quorum-sensing regulator of numerous $X$. fastidiosa virulence factors. Though a few studies have compared host phenotype with bacterial genotype (Andras and Ebert 2013; Li et al. 2008), our study is the first to demonstrate a correlation between host ionome and bacterial pathogen subspecies. The complex and symbiotic nature of the plant host-pathogen relationship, especially for a xylem-limited pathogen, is a likely driver of the observed tobacco phenotype- $X$. fastidiosa genotype correlation.

Generally, an increase in specific elements was observed in tobacco leaves during infection, suggesting that the correlation of the ionome with symptoms is not due solely to gross nutrient deprivation, which might be expected if vascular plugging resulted in reduced transpiration rates $(\mathrm{Hu}$ and Schmidhalter 2005; Sanchez-Rodriguez et al. 2010). Furthermore, bacterial populations in the petioles were largely indistinguishable between aggressive and nonaggressive isolates, consistent with previous analyses of PD-affected grapevines showing no correlation between leaf-scorch symptoms and bacterial populations in host leaves and petioles (Gambetta et al. 2007). Previous research on grapes (Krivanek and Walker 2005) indicated that, although bacterial populations in the petiole were somewhat informative of resistant or susceptible status for most cultivars tested, stem populations were better discriminants. Bacterial populations in the stem were not quantified in this study, so a relationship between stem bacterial populations and isolate aggressiveness cannot be discarded. Furthermore, though tylose formation in grapes is important for xylem plugging during $X$. fastidiosa infection (Sun et al. 2013), tylose formation does not occur in tobacco (Bonsen and Kucera 1990; Mueller and Morgham 1996). Collectively, these results suggest that xylemplugging alone is not a likely explanation for the nutrient modifications observed here. Instead, these may be explained by more complex effects that result from the interactions between $X$. fastidiosa and tobacco.

Plant mineral nutrients are involved in the interactions between plant hosts and microorganisms (Carvalhais et al. 2013; Fones et al. 2010; Musetti et al. 2013; Yuan et al. 2010; Zhao et al. 2013). Among plant-host nutrition-directed effects on bacteria, host nutrient limitations have been shown to alter root exudates, directly affecting gene expression of beneficial rhizobacteria (Carvalhais et al. 2013), while host metal hyperaccumulation confers resistance against plant-pathogenic Pseudomonas syringae pv. maculicola (Fones et al. 2010). Conversely, several vascular bacterial pathogens have been shown to influence the nutrient status of their host plants. The xylem-inhabiting plant pathogen, Xanthomonas oryzae pv. oryzae, can transcriptionally activate a gene in the rice host to promote the removal of $\mathrm{Cu}$ from host xylem vessels (Yuan et al. 2010), contributing to bacterial virulence. Furthermore, infection of citrus plants with 'Candidatus Liberibacter asiaticus', the phloem-limited bacterial causal agent of citrus greening disease, induces host expression of a small RNA associated with $\mathrm{P}$ starvation, suggesting that $\mathrm{P}$ deficiency is a contributing
A
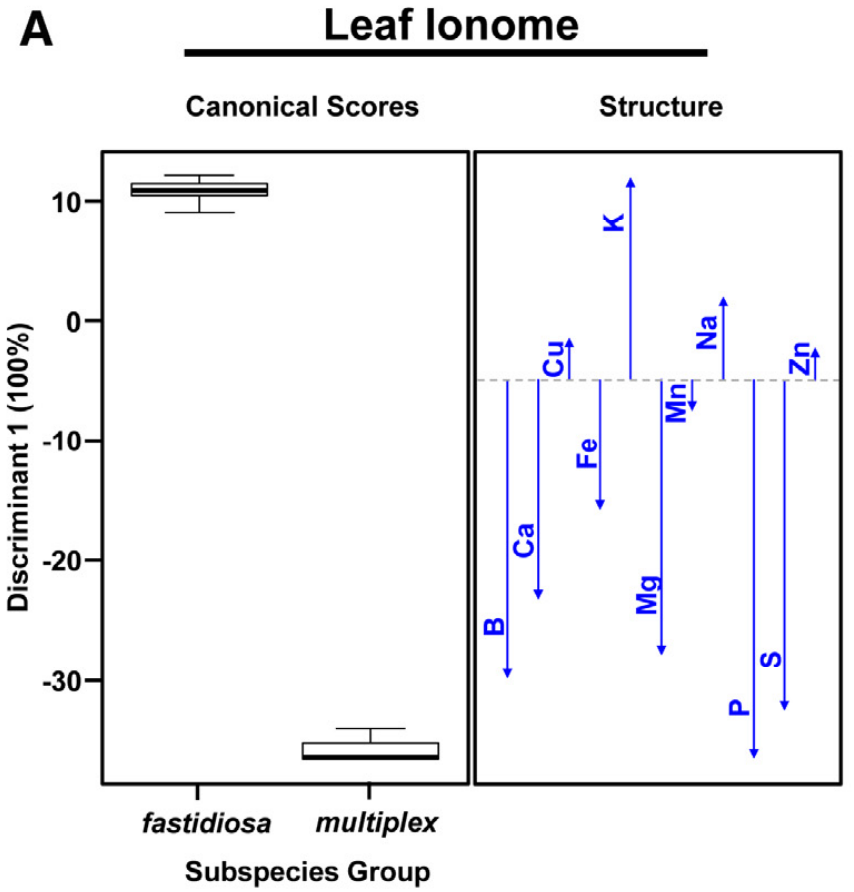

B Sap lonome

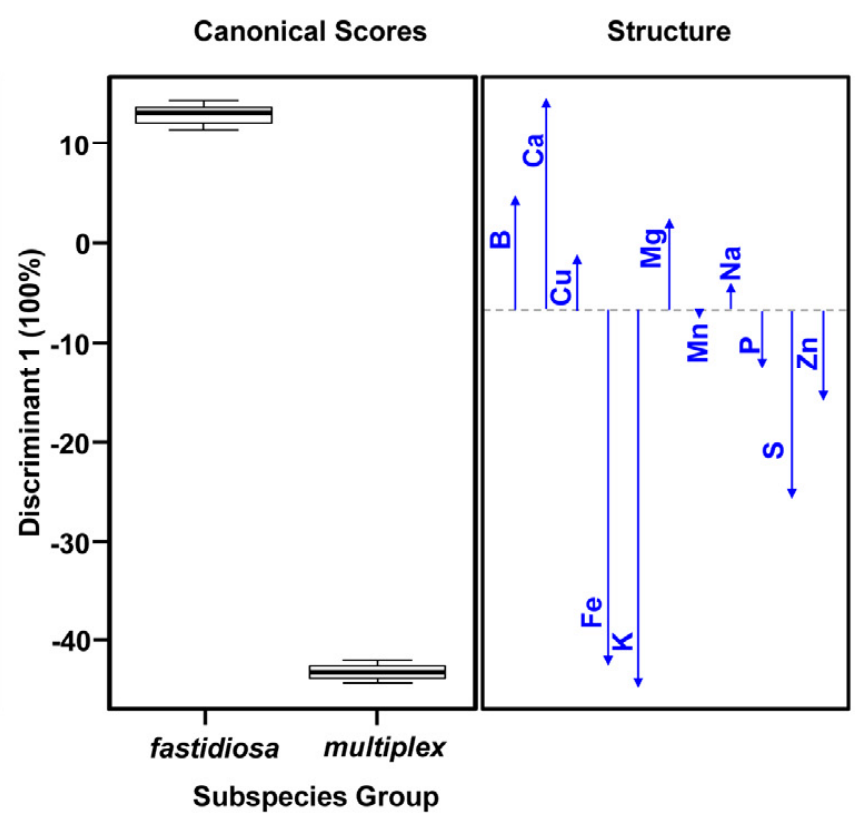

Fig. 4. Canonical discriminant analyses using either $\mathbf{A}$, the host leaf ionome data or $\mathbf{B}$, the host sap ionome data to discriminate between ionome means from Xylella fastidiosa subsp. fastidiosa and X. fastidiosa subsp. multiplex. The separation based on canonical scores is shown on the left of each panel, and the structure of the mineral element separation into two groups is shown on the right of each panel. 
factor in the observed nutrient deficiency-like symptoms (Zhao et al. 2013).

In the tobacco- $X$. fastidiosa interaction studied here, increased Ca levels in infected, symptomatic host plants are consistently reproduced from the previous study (De La Fuente et al. 2013), substantiating the role of $\mathrm{Ca}$ in plant host-X. fastidiosa interactions. Further support for this is the fact that $\mathrm{Ca}$ accumulates in $X$. fastidiosa-occluded xylem vessels (Leite et al. 2002), and Ca-oxalate crystals (known to form under conditions of high calcium concentrations) (Pilbeam and Morely 2007) have been detected in the xylem vessels of grapes and coffee plants after X. fastidiosa infection (Fritschi et al. 2008; Queiroz-Voltan et al. 1998; Tyson et al. 1985). The tobacco leaf $\mathrm{P}$ reduction observed previously (De La Fuente et al. 2013) was not reproduced, but the total content of $P$ in leaves in this study ( $8.5 \mathrm{mg}$ per gram of tissue) was considerably higher than in the previous study (2.7 $\mathrm{mg}$ per gram of tissue) (De La Fuente et al. 2013). This difference could be attributed to a different batch of soil used, since all the other conditions, including fertilization regime, were kept constant between the two studies. The clear symptoms observed here suggest that $\mathrm{P}$ deficiency is not a requisite for the development of symptoms, although it may be involved in symptom severity.

The prevailing understanding of how X. fastidiosa causes disease in plant hosts involves the disruption of water flow as a result of either bacterial biofilm, tylose formation, or both that clogs xylem vessels (Chatterjee et al. 2008). Therefore, the $\mathrm{Ca}$ increase could be the result of a drought or water deficit response; however, other studies that have looked specifically at drought responses in plants have not shown increased $\mathrm{Ca}$ levels, with some showing no change in leaf $\mathrm{Ca}$ concentrations (Sanchez-Rodriguez et al. 2010; Peuke and Rennenberg 2011) and others showing a slight decrease in accumulation $(\mathrm{Hu}$ and Schmidhalter 2005). In a recent study (Choi et al. 2013), which used a microarray to assess grapevine gene expression changes in conditions of $X$. fastidiosa infection and drought, significantly increased expression of select $\mathrm{Ca}$ transport genes was observed in infected grapevine and in infected grapevine under drought conditions but not under drought conditions alone. Moreover, whole transcriptome analysis of $X$. fastidiosainfected citrus plants indicated that genes related to Ca signaling are upregulated upon $X$. fastidiosa infection (Rodrigues et al. 2013). These transcriptional studies suggest that the host plant may be using transport of $\mathrm{Ca}$ as a defense response. We hypothesize that $\mathrm{Ca}$ increase may contribute to increased host symptoms instead of effectively providing a defense against infection. This undesirable result of the $\mathrm{Ca}$ response is similar for the phloem-limited bacterial pathogen, 'Candidatus Phytoplasma vitis'. ' $\mathrm{Ca}$. Phytoplasma vitis' induces $\mathrm{Ca}$ influx into the sieve tubes of the plant to limit phytoplasma spread, which ultimately causes sieve tube occlusions that disrupt photoassimilate distribution within the host plant and causes symptoms (Musetti et al. 2013).

The host leaf ionome was better for differentiating between isolates and symptoms than the host sap ionome. These findings agree with work in Arabidopsis showing that leaves are more stable indicators of plant physiological status than shoots or roots (Baxter et al. 2008). Since xylem sap composition varies considerably from day to day and even within minutes (Schurr 1998), testing of sap at a single timepoint is likely not representative of the xylem conditions $X$. fastidiosa encounters throughout the time course of the disease. Furthermore, since the sap-sampling method used here is destructive to the plant, time course sap sampling is not possible. Since nutrient translocation from roots to leaves takes place in the xylem vessels, increases or decreases in leaf concentrations must be indicative of increased or reduced nutrient conditions in the xylem, espe- cially in the case of a phloem-immobile element like $\mathrm{Ca}$ (Pilbeam and Morely 2007), though the exact duration or relative extent that such conditions persist is ultimately indeterminable either by single timepoint sap extractions or leaf mineral element composition measurements. Changes in the mineral element concentrations in sap may have important effects on $X$. fastidiosa virulence, as increased availability of $\mathrm{Ca}$ has been shown to modulate $X$. fastidiosa virulence traits (Andersen et al. 2007; Cobine et al. 2013; Cruz et al. 2012), and Ca and Mg increase planktonic growth and cell aggregation in xylem sap in vitro (Andersen et al. 2007).

Though unexpected, the reduced virulence of the $X$. fastidiosa Temecula-1 used here has been shown for other bacterial pathogens maintained in the laboratory for multiple years (Fux et al. 2005). Concurrent with the experiments presented here, two other independent experiments conducted in our laboratory showed the same reduction in virulence of the isolate we have designated Temecula- ${ }^{*}$ (unpublished results). Subsequently, the source $X$. fastidiosa strain Temecula-1 was reacquired and, under current greenhouse conditions, the ionome modifications and levels of symptoms seen previously (De La Fuente et al. 2013) have been reproduced (F. Navarrete unpublished results). Interestingly, Temecula- $1^{*}$, which showed reduced virulence as compared with Temecula-1, used in our previous study (De La Fuente et al. 2013) in terms of leaf scorch symptoms and infectivity, also caused very little effect on the host ionome, despite successful petiole colonization $\left(1.4 \times 10^{6} \mathrm{CFU} / \mathrm{g}\right.$ in leaves here vs. $5.9 \times 10^{6} \mathrm{CFU} / \mathrm{g}$ previously $)$. Comparative genomics between Temecula- 1 and Temecula- $1 *$ may therefore be useful to unveil factors potentially involved in virulence and ionome modification.

Here, relationships found between the host ionome, host symptom abundance, host colonization, and pathogen genetics show the value of the host ionome as a phenotypic character of disease and of examining it in the context of other infection traits. Ionome changes, especially $\mathrm{Ca}$ alterations, have been shown, in numerous plants, to defend against stress, including bacterial pathogen invasion (Kanchiswamy et al. 2013; Lecourieux et al. 2006). If this is a response to the presence of the pathogen, it remains to be determined how the plant senses $X$. fastidiosa and how symptoms believed to be caused by xylem transpiration stream blockage (Dandekar et al. 2012; Goodwin et al. 1988) could be directly related to isolate genotype. It is possible that the ionome remodeling is a cascade induced by variable symptom abundance, with more symptoms leading to more stress, which leads to more remodeling. This model also requires plant recognition of differences in $X$. fastidiosa isolates to cause the variable symptoms produced, presumably by mechanisms other than xylem blockage alone. Therefore, it is likely that the ionome changes and symptoms demonstrated here result from an as-yet-unidentified common trigger, suggesting a testable hypothesis that individual isolates produce different levels of a plant-detectable signal during infection that affect the magnitude of the response. By understanding these effects, particularly those of $\mathrm{Ca}$, new control methods could be developed to combat this destructive disease.

\section{MATERIALS AND METHODS}

\section{Greenhouse experiments.}

Bacterial isolates and culture conditions. Xylella fastidiosa isolates consisted of $10 \mathrm{X}$. fastidiosa subsp. fastidiosa isolates originally isolated from grape or elderberry in California, Texas, Georgia, and Florida, as well as three $X$. fastidiosa subsp. multiplex isolates from blueberry in Florida and Georgia (Table 3). These isolates represent 13 different, diverse haplotypes within $X$. fastidiosa subsp. fastidiosa and $X$. fastidiosa 
subsp. multiplex based on MLSA-E conducted previously (Parker et al. 2012) or here (isolates AlmaEm3, EB92-1, and Temecula- ${ }^{*}$, data not shown). Isolate AlmaEm3 was isolated in 2011 in Alma, GA, U.S.A., from an infected blueberry Vaccinium corymbosum 'Emerald', a cultivar suggested to be tolerant or resistant to $X$. fastidiosa. Isolate EB92-1, isolated from an elderberry (Sambucus canadensis L.) in Leesburg, FL, U.S.A., has been suggested to be benign on grapevine (Hopkins 2005). The isolate referred to here as Temecula- $1 *$ was originally included as the $X$. fastidiosa type strain Temecula-1; however, it became apparent during these experiments that this isolate has reduced virulence versus the wild-type Temecula-1 used previously (De La Fuente et al. 2013) in terms of leafscorch symptoms observed $(35 \%$ of leaves in this study vs. $60 \%$ in our previous study) and infectivity (56\% of inoculated plants here [Table 1] vs. 93\% previously). Sequencing of the nine MLSA-E genes examined previously (Parker et al. 2012) indicated no genetic differences between Temecula- $1^{*}$ and Temecula-1; therefore, the isolate used in this study is referred to as Temecula- $1 *$ to note its lower virulence. For 1 week prior to inoculation, isolates were grown on periwinkle wilt medium at $28^{\circ} \mathrm{C}$ and then suspended in succinate-citrate-phosphate buffer, as previously described (De La Fuente et al. 2013).

Tobacco growth and inoculation. Tobacco cultivar SR1 'Petite Havana' (plant introduction number 552516) was used in these experiments (De La Fuente et al. 2013; Francis et al. 2008). Seeds were obtained from the United States Department of Agriculture (USDA) Germplasm Resources Information Network. Plants were grown in the greenhouse at 20 to $25^{\circ} \mathrm{C}$ with natural sunlight in 4.5 inch square pots with Sunshine Mix \#8 (Sun Gro Horticulture Canada Ltd., Vancouver, Canada). Plants were watered regularly and were given fertilizer whenever leaves began to yellow (Peter's Professional 20-10-20 PeatLite Special; The Scotts Company, Marysville, OH, U.S.A.). Tobacco plants were inoculated at the five-to-six true-leaf stage using a 1-ml tuberculin syringe on the lowest three true leaves on each plant as described previously (De La Fuente et al. 2013), with droplets of inoculum containing about $10^{8} \mathrm{X}$. fastidiosa cells per milliliter. Leaves above the point of inoculation were removed at the time of inoculation and the plant was allowed to regrow from that point. Eight plants were inoculated per isolate treatment, and inoculation with buffer only was used as a control treatment. Two replicate experiments were performed.

Disease progression and monitoring for symptoms. Following inoculation, plants were grown in the greenhouse for 2 to 3 months until leaf-scorch symptoms became evident, and at 63 and $80 \mathrm{dpi}$, samples were collected from four plants per treatment. Plants were assessed weekly for the appearance of symptoms (Table 1) via comparison with the buffer control plants. Plant heights (length of the main stem) were measured weekly. To confirm leaf-darkening symptoms, leaf samples $(10 \mathrm{mg})$ from collected leaves were analyzed for chlorophyll A and B content according to a previously described spectrophotometric method (Wintermans and Demots 1965) and were compared with buffer control leaves to detect significantly higher chlorophyll contents $(P<0.05)$. To more easily compare the relative virulence of each isolate, symptom observations by isolate were condensed into a single numeric RSI score as follows: two points were given to isolates causing leaf scorch in more than $50 \%$ of plants (an " $X$ " on Table 1), and one point was given to isolates causing scorch in 33 to $50 \%$ of plants (a " \pm " on Table 1); either one or 0.5 points were given for isolates causing leaf curling or cupping, intraveinal chlorosis, vein bleaching, or leaf darkening symptoms, singly or in combination, in $>50 \%$ or 33 to $50 \%$ of plants, respectively; and one point was given to isolates causing significant $(P<0.05)$ reductions in plant height.

\section{Bacterial quantification.}

To determine if inoculated plants became infected with $X$. fastidiosa, total DNA was extracted from petiolar portions of three leaves from above the inoculation point, using a modified CTAB protocol (Doyle and Doyle 1987). Leaves were collected upon harvest of each plant at the two collection timepoints (63 and $80 \mathrm{dpi}$ ) and sections of the lower petioles were excised as previously described (De La Fuente et al. 2013). X. fastidiosa CFU per gram of extracted petiole tissue were enumerated via quantitative polymerase chain reaction (qPCR), relative to a four-point standard curve prepared from DNA from known CFU from pure cultures, as described previously (De La Fuente et al. 2013). The potential for plant material to interfere with qPCR amplification efficiency was not considered for the standard curves. Due to the fact that the original TaqMan probe sequence did not match the $X$. fastidiosa subsp. multiplex isolates, the probe was redesigned including a degenerate base to prevent inaccurate estimates in CFU per gram due to low probe specificity. The sequence of the redesigned probe was: TGGCAGGCAGCAAYGATACGGCT. All reported qPCR results were generated using the redesigned probe, though results did not differ substantially based on probe usage (data not shown). Successful infection was defined by the presence of detectable $X$. fastidiosa populations in petioles of leaves above the inoculation point. For successfully infected plants from

Table 3. Xylella fastidiosa isolates used in this analysis, the host they were isolated from, the location of their isolation, and the isolate source

\begin{tabular}{|c|c|c|c|c|c|c|}
\hline Subspecies/isolate & Host name & Host species & City & County & State & Source \\
\hline \multicolumn{7}{|l|}{ multiplex } \\
\hline AlmaEm3 & Blueberry & Vaccinium 'Emerald' & Alma & Bacon & Georgia & This study \\
\hline BB08-1 & Blueberry & Vaccinium 'Windsor' & Palatka & Putnam & Florida & D. Hopkins (University of Florida) \\
\hline BBI64 & Blueberry & Vaccinium 'V1' & Hoboken & Brantley & Georgia & H. Scherm (University of Georgia) \\
\hline \multicolumn{7}{|l|}{ fastidiosa } \\
\hline CCPM1 & Grape & Vitis vinifera 'Petit Manseng' & Dahlonega & Lumpkin & Georgia & Parker et al. 2011 \\
\hline ConnCreek & Grape & Vitis vinifera & Rutherford & Napa & California & $\begin{array}{l}\text { R. Almeida (University of California, } \\
\text { Berkeley) }\end{array}$ \\
\hline EB92-1 & Elderberry & Sambucus sp. & Leesburg & Lake & Florida & Hopkins 2005 \\
\hline GilBec625 & Grape & Vitis vinifera 'Viognier' & Stonewall & Gillespie & Texas & M. Black (Texas A\&M University) \\
\hline King3 & Grape & Vitis vinifera & Kingsburg & Fresno & California & J. Chen (USDA, Parlier, CA) \\
\hline Napa-Silverado & Grape & Vitis vinifera & Napa & Napa & California & $\begin{array}{l}\text { R. Almeida (University of California, } \\
\text { Berkeley) }\end{array}$ \\
\hline PD92-8 & Bunch Grape & Vitis sp. 'BN6 Sou-1' & Leesburg & Lake & Florida & Hopkins 2005 \\
\hline Teme4 & Grape & Vitis vinifera & Temecula & Riverside & California & J. Chen (USDA, Parlier, CA) \\
\hline Temecula-1* & Grape & Vitis vinifera & Temecula & Riverside & California & Van Sluys et al., 2005; this study \\
\hline WM1-1 & Grape & Vitis vinifera 'Mourvedre' & Dahlonega & Lumpkin & Georgia & Parker et al. 2011 \\
\hline
\end{tabular}


both timepoints from two replicated experiments, CFU per gram from a single petiole per plant (most basal $X$. fastidiosapositive leaf) was averaged for each $X$. fastidiosa isolate $(n=9$ to 16$)$.

\section{Plant ionome characterization.}

Leaf ionomes. Every leaf above the inoculation point from every plant was collected for characterization of the plant ionome. In total, leaves from four plants were used per timepoint per treatment. After removal of the petioles from the three lowest leaves above the inoculation point for DNA extraction and qPCR analysis (described above), leaves were prepared for and analyzed by ICP-OES (Perkin Elmer 7100 DV, Waltham, MA, U.S.A.) as described previously (De La Fuente et al. 2013).

Sap ionomes. After leaves were removed for ionome analysis, sap was extracted from tobacco plants using the root exudate method described previously (Liang and Zhang 1997). Briefly, the roots of the plant were placed into a Model 600 pressure chamber (PMS Instrument Company, Corvallis, OR, U.S.A.) and a single cut was made through the stem of the plant. Sap was removed from the cut end after pressure was applied to the roots and was collected into a 1.7-ml microcentrifuge tube for subsequent analysis. One $200-\mu 1$ sample of sap was collected from each plant, was diluted to $800 \mu$ with ultrapure mineralfree water, and was analyzed via ICP-OES as described for the leaf analysis above. Due to the lengthy collection times associated with this procedure, sap was collected from one plant per treatment per timepoint for the first experiment, one plant per treatment for timepoint 1 from the second experiment, and three plants per treatment for timepoint 2 from the second experiment.

\section{DNA sequence analysis.}

For isolate Temecula- ${ }^{*}$, the nine MLSA-E genes (Parker et al. 2012) were sequenced from infected leaf samples obtained from the greenhouse experiments described above, confirming they were identical to Temecula-1. Homologous MLSA-E gene regions were downloaded from the draft genomes of strains EB92-1 (accession number AFDJ00000000) (Zhang et al. 2011) and AlmaEm3 (GenBank accession numbers KF445148 to KF445154). For target gene regions unavailable in the draft genomes (EB92-1: copB, pilA; AlmaEm3: fimA, pilA), PCR and sequence analysis was performed as previously described (Parker et al. 2012) to obtain these sequences (GenBank accession numbers KF437626 to KF437629). This confirmed each isolate used in this study was of a unique haplotype.

\section{Statistical analysis.}

All analyses were performed in the $\mathrm{R}$ language for statistical computing (Ihaka and Gentleman 1996). Linear random effects models were fit to the data from infected plants to model individual leaf mineral element response to isolate type (function lmer from lme4 $\mathrm{R}$ package) (Bates et al. submitted). This type of model was used to control for random effects due to experiment, plant position, timepoint, and control for pseudoreplication at the plant level (i.e., multiple leaves per plant). The mean values for each isolate-mineral element combination were extracted from the mixed effects models and were used for multivariate analyses. PCA of the correlation matrix was used to investigate ionome responses to infection by different isolate types. Once groups were identified from PCA, CDA was used to determine which ionome mineral elements discriminated between groups. Partial Mantel tests (Legendre and Fortin 2010; Mantel 1967; Smouse et al. 1986) were used to investigate whether a correlation existed between a genetic distance matrix of the 13 isolates created using Bayesian phylogenetic analyses implemented in MrBayes version 3.1.2 (Ronquist and
Huelsenbeck 2003), as previously described (Parker et al. 2012), and an ionome Euclidian distance matrix created from a phylogeny constructed using the Fitch-Margoliash criterion (Fitch and Margoliash 1967), a weighted least-squares method (Felsenstein 1997) implemented in PHYLIP (Felsenstein 2005) on T-REX (Boc et al. 2012). Virulence differences between isolates were controlled for in the Mantel test because our data indicated a relationship between virulence and host ionome.

\section{ACKNOWLEDGMENTS}

We thank J. M. Brannon for his substantial assistance with greenhouse experiments, as well as C. Moore for contributions to the qPCR analysis. We also thank L. Cruz, L. Bond, B. Fairless, C. Fields, J. Hudson, J. Johnson, L. Liu, M. Moore, K. Schultz, J. Wilder, and S. McCarty for their assistance with sample processing. Additionally, we thank the Auburn University Plant Science Research Center for greenhouse space and support, as well as A. Wright (Auburn University) for use of the pressure chamber, and A. Retchless (University of California, Berkeley) for providing DNA sequence data. We thank S. Lindow (University of California, Berkeley) for providing a new stock of Temecula-1. We also appreciate R. Almeida (University of California, Berkeley), M. Black (Texas A\&M University), D. Hopkins (University of Florida), J. Chen (USDA, Parlier, CA), and H. Scherm (University of Georgia) for providing isolates used in this study. Portions of this research were funded by a USDA-AFRI grant (\#201065108-20633), an AAES-Hatch grant (\#0217494), as well as a MARC U*STAR Award.

\section{LITERATURE CITED}

Alves, E., Kitajima, E. W., and Leite, B. 2003. Interaction of Xylella fastidiosa with different cultivars of Nicotiana tabacum: a comparison of colonization patterns. J. Phytopathol. 151:500-506.

Andersen, P. C., Brodbeck, B. V., Oden, S., Shriner, A., and Leite, B. 2007. Influence of xylem fluid chemistry on planktonic growth, biofilm formation and aggregation of Xylella fastidiosa. FEMS (Fed. Eur. Microbiol. Soc.) Microbiol. Lett. 274:210-217.

Andras, J. P., and Ebert, D. 2013. A novel approach to parasite population genetics: Experimental infection reveals geographic differentiation, recombination and host-mediated population structure in Pasteuria ramosa, a bacterial parasite of Daphnia. Mol. Ecol. 22:972-986.

Baccari, C., and Lindow, S. E. 2011. Assessment of the process of movement of Xylella fastidiosa within susceptible and resistant grape cultivars. Phytopathology 101:77-84.

Bates, D., Maechler, M., and Bolker, B. lme4: Linear mixed-effects models using S4 classes. The R Project for Statistical Computing http://CRAN.R-project.org/package=lme4. Published online.

Baxter, I., and Dilkes, B. P. 2012. Elemental profiles reflect plant adaptations to the environment. Science 336:1661-1663.

Baxter, I. R., Vitek, O., Lahner, B., Muthukumar, B., Borghi, M., Morrissey, J., Guerinot, M. L., and Salt, D. E. 2008. The leaf ionome as a multivariable system to detect a plant's physiological status. Proc. Natl. Acad. Sci. U.S.A. 105:12081-12086.

Baxter, I., Hosmani, P. S., Rus, A., Lahner, B., Borevitz, J. O., Muthukumar, B., Mickelbart, M. V., Schreiber, L., Franke, R. B., and Salt, D. E. 2009 Root suberin forms an extracellular barrier that affects water relations and mineral nutrition in Arabidopsis. PLoS Genet 5. Published online.

Boc, A., Diallo, A. B., and Makarenkov, V. 2012. T-REX: A web server for inferring, validating and visualizing phylogenetic trees and networks. Nucleic Acids Res. 40:W573-W579.

Bonsen, K. J. M., and Kucera, L. J. 1990. Vessel occlusions in plantsMorphological, functional and evolutionary aspects. IAWA Bull. 11:393-399.

Carazzolle, M. F., Rabello, F. R., Martins, N. F., de Souza, A. A., do Amaral, A. M., Freitas-Astua, J., Pereira, G. A. G., Machado, M. A., and Mehta, A. 2011. Identification of defence-related genes expressed in coffee and citrus during infection by Xylella fastidiosa. Eur. J. Plant Pathol. 130:529-540.

Carvalhais, L. C., Dennis, P. G., Fan, B., Fedoseyenko, D., Kierul, K., Becker, A., von Wiren, N., and Borriss, R. 2013. Linking plant nutritional status to plant-microbe interactions. PLoS One 8:e68555. Published online.

Chang, C. J., Donaldson, R., Brannen, P., Krewer, G., and Boland, R. 2009. Bacterial leaf scorch, a new blueberry disease caused by Xylella fastidiosa. Hortscience 44:413-417. 
Chao, D. Y., Gable, K., Chen, M., Baxter, I., Dietrich, C. R., Cahoon, E. B., Guerinot, M. L., Lahner, B., Lu, S. Y., Markham, J. E., Morrissey, J., Han, G. S., Gupta, S. D., Harmon, J. M., Jaworski, J. G., Dunn, T. M., and Salt, D. E. 2011. Sphingolipids in the root play an important role in regulating the leaf ionome in Arabidopsis thaliana. Plant Cell 23:10611081

Chatterjee, S., Almeida, R. P. P., and Lindow, S. 2008. Living in two worlds: The plant and insect lifestyles of Xylella fastidiosa. Ann. Rev. Phytopathol. 46:243-271.

Choat, B., Gambetta, G. A., Wada, H., Shackel, K. A., and Matthews, M. A. 2009. The effects of Pierce's disease on leaf and petiole hydraulic conductance in Vitis vinifera cv. Chardonnay. Physiol. Plant. 136:384394

Choi, H.-K., Iandolino, A., da Silva, F. G., and Cook, D. R. 2013. Water eficit modulates the response of Vitis vinifera to the Pierce's disease pathogen Xylella fastidiosa. Mol. Plant-Microbe Interact. 26:643-657.

Cobine, P. A., Cruz, L. F., Navarrete, F., Duncan, D., Tygart, M., and De La Fuente, L. 2013. Xylella fastidiosa differentially accumulates mineral elements in biofilm and planktonic cells. PLoS One 8. Published online.

Cruz, L. F., Cobine, P. A., and De La Fuente, L. 2012. Calcium increases Xylella fastidiosa surface attachment, biofilm formation, and twitching motility. Appl. Environ. Microbiol. 78:1321-1331.

Dandekar, A. M., Gouran, H., Ibanez, A. M., Uratsu, S. L., Aguero, C. B., McFarland, S., Borhani, Y., Feldstein, P. A., Bruening, G., Nascimento, R., Goulart, L. R., Pardington, P. E., Chaudhary, A., Norvell, M. Civerolo, E., and Gupta, G. 2012. An engineered innate immune defense protects grapevines from Pierce's disease. Proc. Natl. Acad. Sci. U.S.A. 109:3721-3725.

Daugherty, M. P., Lopes, J. R. S., and Almeida, R. P. P. 2010. Strain-specific alfalfa water stress induced by Xylella fastidiosa. Eur. J. Plant Pathol. 127:333-340.

De La Fuente, L., Parker, J. K., Oliver, J. E., Granger, S., Brannen, P. M., van Santen, E., and Cobine, P. A. 2013. The bacterial pathogen Xylella fastidiosa affects the leaf ionome of plant hosts during infection. PLoS One 8. Published online.

De La Fuente, L., Navarrete, F., Oliver, J. E., Cruz, L. F., and Cobine, P. A The influence of metal elements on virulence in plant pathogenic bacteria.In: Virulence Mechanisms in Plant Pathogenic Bacteria. N. Wang, G. Sundin, L. De La Fuente, C. Roper, J. Ham, J. Jones, F. White, and S. Hogenhout, eds. American Phytopathological Society Press. St. Paul, MN, U.S.A. In press.

Doyle, J., and Doyle, J. L. 1987. A rapid DNA isolation procedure for small quantities of fresh leaf tissue. Phytochem. Bull. 19:11-15.

Felsenstein, J. 1997. An alternating least squares approach to inferring phylogenies from pairwise distances. Syst. Biol. 46:101-111.

Felsenstein, J. 2005. PHYLIP (Phylogeny Inference Package) version 3.6. Department of Genome Sciences, University of Washington, Seattle.

Fitch, W. M., and Margoliash, E. 1967. Construction of phylogenetic trees. Science 155:279-284

Fones, H., and Preston, G. M. 2013. The impact of transition metals on bacterial plant disease. FEMS (Fed. Eur. Microbiol. Soc.) Microbiol. Rev. 37:495-519.

Fones, H., Davis, C. A. R., Rico, A., Fang, F., Smith, J. A. C., and Preston, G. M. 2010. Metal hyperaccumulation armors plants against disease. PLoS Pathog. 6. Published online.

Francis, M., Civerolo, E. L., and Bruening, G. 2008. Improved bioassay of Xylella fastidiosa using Nicotiana tabacum cultivar SR1. Plant Dis. 92:14-20.

Fritschi, F. B., Lin, H., and Walker, M. A. 2008. Scanning electron microscopy reveals different response pattern of four Vitis genotypes to Xylella fastidiosa infection. Plant Dis. 92:276-286.

Fux, C. A., Shirtliff, M., Stoodley, P., and Costerton, J. W. 2005. Can laboratory reference strains mirror 'real-world' pathogenesis? Trends Microbiol. $13: 58-63$

Gambetta, G. A., Fei, J., Rost, T. L., and Matthews, M. A. 2007. Leaf scorch symptoms are not correlated with bacterial populations during Pierce's disease. J. Exp. Bot. 58:4037-4046.

Goodwin, P. H., Devay, J. E., and Meredith, C. P. 1988. Physiological responses of Vitis vinifera cv. Chardonnay to infection by the Pierce's disease bacterium. Physiol. Mol. Plant 32:17-32.

Hood, M. I., and Skaar, E. P. 2012. Nutritional immunity: transition metals at the pathogen-host interface. Nat. Rev. Microbiol. 10:525-537.

Hopkins, D. L. 2005. Biological control of Pierce's disease in the vineyard with strains of Xylella fastidiosa benign to grapevine. Plant Dis. 89:1348-1352.

Hu, Y. C., and Schmidhalter, U. 2005. Drought and salinity: A comparison of their effects on mineral nutrition of plants. J. Plant Nutr. Soil Sc. 168:541-549.

Ihaka, R., and Gentleman, R. 1996. R: A language for data analysis and graphics. J. Comput. Graph. Stat. 5:299-314.

Janse, J. D., and Obradovic, A. 2010. Xylella fastidiosa: Its biology, diagnosis, control and risks. J. Plant Pathol. 92:S35-S48.

Kanchiswamy, C. N., Mohanta, T. K., Capuzzo, A., Occhipinti, A., Verrillo, F., Maffei, M. E., and Malnoy, M. 2013. Differential expression of CPKs and cytosolic $\mathrm{Ca}^{2+}$ variation in resistant and susceptible apple cultivars (Malus $\times$ domestica) in response to the pathogen Erwinia amylovora and mechanical wounding. BMC Genomics 14:760.

Killiny, N., and Almeida, R. P. P. 2011. Gene regulation mediates host specificity of a bacterial pathogen. Environ. Microbiol. Rep. 3:791-797.

Krivanek, A. F., and Walker, M. A. 2005. Vitis resistance to Pierce's disease is characterized by differential Xylella fastidiosa populations in stems and leaves. Phytopathology 95:44-52.

Lahner, B., Gong, J. M., Mahmoudian, M., Smith, E. L., Abid, K. B., Rogers, E. E., Guerinot, M. L., Harper, J. F., Ward, J. M., McIntyre, L., Schroeder, J. I., and Salt, D. E. 2003. Genomic scale profiling of nutrient and trace elements in Arabidopsis thaliana. Nat. Biotechnol. 21:12151221

Lecourieux, D., Raneva, R., and Pugin, A. 2006. Calcium in plant defencesignalling pathways. New Phytol. 171:249-269.

Legendre, P., and Fortin, M. J. 2010. Comparison of the Mantel test and alternative approaches for detecting complex multivariate relationships in the spatial analysis of genetic data. Mol. Ecol. Resour. 10:831-844.

Leite, B., Ishida, M. L., Alves, E., Carrer, H., Pascholati, S. F., and Kitajima, E. W. 2002. Genomics and X-ray microanalysis indicate that $\mathrm{Ca}^{2+}$ and thiols mediate the aggregation and adhesion of Xylella fastidiosa. Braz. J. Med. Biol. Res. 35:645-650.

Li, M., Wang, B. H., Zhang, M. H., Rantalainen, M., Wang, S. Y., Zhou, H. K., Zhang, Y., Shen, J., Pang, X. Y., Zhang, M. L., Wei, H., Chen, Y., Lu, H. F., Zuo, J., Su, M. M., Qiu, Y. P., Jia, W., Xiao, C. N., Smith, L. M., Yang, S. L., Holmes, E., Tang, H. R., Zhao, G. P., Nicholson, J. K., Li, L. J., and Zhao, L. P. 2008. Symbiotic gut microbes modulate human metabolic phenotypes. Proc. Natl. Acad. Sci. U.S.A. 105:21172122

Liang, J. S., and Zhang, J. H. 1997. Collection of xylem sap at flow rate similar to in vivo transpiration flux. Plant Cell Physiol. 38:1375-1381.

Lopes, J. R. S., Daugherty, M. P., and Almeida, R. P. P. 2010. Strain origin drives virulence and persistence of Xylella fastidiosa in alfalfa. Plant Pathol. 59:963-971.

Lopes, S. A., Ribeiro, D. M., Roberto, P. G., Franca, S. C., and Santos, J. M. 2000. Nicotiana tabacum as an experimental host for the study of plant-Xylella fastidiosa interactions. Plant Dis. 84:827-830.

Mantel, N. 1967. Detection of disease clustering and a generalized regression approach. Cancer Res. 27:209-220.

Mueller, W. C., and Morgham, A. T. 1996. Ultrastructure of the vascular responses of tobacco to Fusarium oxysporum $\mathrm{f}$ sp nicotianae. Can. J. Bot. 74:1273-1278

Munns, R., James, R. A., Xu, B., Athman, A., Conn, S. J., Jordans, C., Byrt, C. S., Hare, R. A., Tyerman, S. D., Tester, M., Plett, D., and Gilliham, M. 2012. Wheat grain yield on saline soils is improved by an ancestral $\mathrm{Na}^{+}$transporter gene. Nat. Biotechnol. 30:360-U173.

Musetti, R., Buxa, S. V., De Marco, F., Loschi, A., Polizzotto, R., Kogel, K. H., and van Bel, A. J. E. 2013. Phytoplasma-triggered $\mathrm{Ca}^{2+}$ influx is involved in sieve-tube blockage. Mol. Plant-Microbe Interact. 26:379386.

Nunney, L., Yuan, X. L., Bromley, R., Hartung, J., Montero-Astua, M., Moreira, L., Ortiz, B., and Stouthamer, R. 2010. Population Genomic analysis of a bacterial plant pathogen: Novel insight into the origin of Pierce's disease of grapevine in the US. PLoS One 5. Published online.

Nunney, L., Elfekih, S., and Stouthamer, R. 2012. The importance of multilocus sequence typing: Cautionary tales from the bacterium Xylella fastidiosa. Phytopathology 102:456-460.

Nunney, L., Vickerman, D. B., Bromley, R. E., Russell, S. A., Hartman, J. R., Morano, L. D., and Stouthamer, R. 2013. Recent evolutionary radiation and host plant specialization in the Xylella fastidiosa subspecies native to the United States. Appl. Environ. Microbiol. 79:2189-2200.

Parker, J. K., Havird, J. C., and De La Fuente, L. 2012. Differentiation of Xylella fastidiosa strains via multilocus sequence analysis of environmentally mediated genes (MLSA-E). Appl. Environ. Microbiol. 78:13851396.

Perez-Donoso, A. G., Greve, L. C., Walton, J. H., Shackel, K. A., and Labavitch, J. M. 2007. Xylella fastidiosa infection and ethylene exposure result in xylem and water movement disruption in grapevine shoots. Plant Physiol. 143:1024-1036.

Peuke, A. D., and Rennenberg, H. 2011. Impacts of drought on mineral macro- and microelements in provenances of beech (Fagus sylvatica L.) seedlings. Tree Physiol. 31:196-207.

Pilbeam, D. J., and Morely, P. S. 2007. Calcium. Pages 121-144 in: Handbook of Plant Nutrition, A. V. Barker, and D. J. Pilbeam, ed. CRC Press, Boca Raton, FL, U.S.A. 
Purcell, A. H., and Hopkins, D. L. 1996. Fastidious xylem-limited bacterial plant pathogens. Ann. Rev. Phytopathol. 34:131-151.

Queiroz-Voltan, R. B., Paradela Filho, O., Carelli, M. L. C., and Fahl, J. I. 1998. Aspectos estruturais de cafeeiro infectado com Xylella fastidiosa. Bragantia 57.

Rodrigues, C. M., de Souza, A. A., Takita, M. A., Kishi, L. T., and Machado, M. A. 2013. RNA-Seq analysis of Citrus reticulata in the early stages of Xylella fastidiosa infection reveals auxin-related genes as a defense response. BMC Genomics 14:676.

Rogers, E. E. 2012. Evaluation of Arabidopsis thaliana as a model host for Xylella fastidiosa. Mol. Plant-Microbe Interact. 25:747-754.

Ronquist, F., and Huelsenbeck, J. P. 2003. MrBayes 3: Bayesian phylogenetic inference under mixed models. Bioinformatics 19:1572-1574.

Sanchez, D. H., Pieckenstain, F. L., Escaray, F., Erban, A., Kraemer, U., Udvardi, M. K., and Kopka, J. 2011. Comparative ionomics and metabolomics in extremophile and glycophytic Lotus species under salt stress challenge the metabolic pre-adaptation hypothesis. Plant Cell Environ. 34:605-617.

Sanchez-Rodriguez, E., Rubio-Wilhelmi, M. D., Cervilla, L. M., Blasco, B., Rios, J. J., Leyva, R., Romero, L., and Ruiz, J. M. 2010. Study of the ionome and uptake fluxes in cherry tomato plants under moderate water stress conditions. Plant Soil 335:339-347.

Scally, M., Schuenzel, E. L., Stouthamer, R., and Nunney, L. 2005. Multilocus sequence type system for the plant pathogen Xylella fastidiosa and relative contributions of recombination and point mutation to clonal diversity. App. Environ. Microbiol. 71:8491-8499.

Schurr, U. 1998. Xylem sap sampling-New approaches to an old topic. Trends Plant Sci. 3:293-298.

Simpson, A. J. G., Reinach, F. C., Arruda, P., Abreu, F. A., Acencio, M., Alvarenga, R., Alves, L. M. C., Araya, J. E., Baia, G. S., Baptista, C. S., Barros, M. H., Bonaccorsi, E. D., Bordin, S., Bove, J. M., Briones, M. R. S., Bueno, M. R. P., Camargo, A. A., Camargo, L. E. A., Carraro, D. M., Carrer, H., Colauto, N. B., Colombo, C., Costa, F. F., Costa, M. C. R., Costa-Neto, C. M., Coutinho, L. L., Cristofani, M., Dias-Neto, E., Docena, C., El-Dorry, H., Facincani, A. P., Ferreira, A. J. S., Ferreira, V. C. A., Ferro, J. A., Fraga, J. S., Franca, S. C., Franco, M. C., Frohme, M., Furlan, L. R., Garnier, M., Goldman, G. H., Goldman, M. H. S., Gomes, S. L., Gruber, A., Ho, P. L., Hoheisel, J. D., Junqueira, M. L. Kemper, E. L., Kitajima, J. P., Krieger, J. E., Kuramae, E. E., Laigret, F., Lambais, M. R., Leite, L. C. C., Lemos, E. G. M., Lemos, M. V. F., Lopes, S. A., Lopes, C. R., Machado, J. A., Machado, M. A., Madeira, A. M. B. N., Madeira, H. M. F., Marino, C. L., Marques, M. V., Martins, E. A. L., Martins, E. M. F., Matsukuma, A. Y., Menck, C. F. M., Miracca, E. C., Miyaki, C. Y., Monteiro-Vitorello, C. B., Moon, D. H., Nagai, M. A., Nascimento, A. L. T. O., Netto, L. E. S., Nhani, A., Nobrega, F. G., Nunes, L. R., Oliveira, M. A., de Oliveira, M. C., de Oliveira, R. C., Palmieri, D. A., Paris, A., Peixoto, B. R., Pereira, G. A. G., Pereira, H. A., Pesquero, J. B., Quaggio, R. B., Roberto, P. G., Rodrigues, V., Rosa, A. J. D., de Rosa, V. E., de Sa, R. G., Santelli, R. V., Sawasaki, H. E., da Silva, A. C. R., da Silva, A. M., da Silva, F. R., Silva, W. A., da Silveira, J. F., Silvestri, M. L. Z., Siqueira, W. J., de Souza, A. A., de Souza, A.
P., Terenzi, M. F., Truffi, D., Tsai, S. M., Tsuhako, M. H., Vallada, H. Van Sluys, M. A., Verjovski-Almeida, S., Vettore, A. L., Zago, M. A., Zatz, M., Meidanis, J., Setubal, J. C., and Org, X. f. C. 2000. The genome sequence of the plant pathogen Xylella fastidiosa. Nature 406:151-157

Smouse, P. E., Long, J. C., and Sokal, R. R. 1986. Multiple-regression and correlation extensions of the Mantel test of matrix correspondence. Syst Zool. 35:627-632.

Sun, Q., Sun, Y. L., Walker, M. A., and Labavitch, J. M. 2013. Vascular occlusions in grapevines with Pierce's disease make disease symptom development worse. Plant Physiol. 161:1529-1541.

Tyson, G. E., Stojanovic, B. J., Kuklinski, R. F., Divittorio, T. J., and Sullivan, M. L. 1985. Scanning electron microscopy of Pierce's disease bacterium in petiolar xylem of grape leaves. Phytopathology 75:264269.

Van Sluys, M. A., de Oliveira, M. C., Monteiro-Vitorello, C. B., Miyaki, C. Y., Furlan, L. R., Camargo, L. E. A., da Silva, A. C. R., Moon, D. H., Takita, M. A., Lemos, E. G. M., Machado, M. A., Ferro, M. I. T., da Silva, F. R., Goldman, M. H. S., Goldman, G. H., Lemos, M. V. F., ElDorry, H., Tsai, S. M., Carrer, H., Carraro, D. M., de Oliveira, R. C., Nunes, L. R., Siqueira, W. J., Coutinho, L. L., Kimura, E. T., Ferro, E. S., Harakava, R., Kuramae, E. E., Marino, C. L., Giglioti, E., Abreu, I. L., Alves, L. M. C., do Amaral, A. M., Baia, G. S., Blanco, S. R., Brito, M. S., Cannavan, F. S., Celestino, A. V., da Cunha, A. F., Fenille, R. C., Ferro, J. A., Formighieri, E. F., Kishi, L. T., Leoni, S. G., Oliveira, A. R., Rosa, V. E., Sassaki, F. T., Sena, J. A. D., de Souza, A. A., Truffi, D., Tsukumo, F., Yanai, G. M., Zaros, L. G., Civerolo, E. L., Simpson, A. J. G., Almeida, N. F., Setubal, J. C., and Kitajima, J. P. 2003. Comparative analyses of the complete genome sequences of Pierce's disease and citrus variegated chlorosis strains of Xylella fastidiosa. J. Bacteriol 185:1018-1026.

White, P. J., Broadley, M. R., Thompson, J. A., McNicol, J. W., Crawley, M. J., Poulton, P. R., and Johnston, A. E. 2012. Testing the distinctness of shoot ionomes of angiosperm families using the Rothamsted Park Grass continuous hay experiment. New Phytol. 196:101-109.

Wintermans, J. F., and Demots, A. 1965. Spectrophotometric characteristics of chlorophylls A and B and their pheophytins in ethanol. Biochim. Biophys. Acta 109:448-\&.

Yuan, M., Chu, Z. H., Li, X. H., Xu, C. G., and Wang, S. P. 2010. The bacterial pathogen Xanthomonas oryzae overcomes rice defenses by regulating host copper redistribution. Plant Cell 22:3164-3176.

Zhang, S., Flores-Cruz, Z., Kumar, D., Chakrabarty, P., Hopkins, D. L., and Gabriel, D. W. 2011. The Xylella fastidiosa biocontrol strain EB921 genome is very similar and syntenic to Pierce's disease strains. J Bacteriol 193:5576-5577.

Zhao, H. W., Sun, R. B., Albrecht, U., Padmanabhan, C., Wang, A. R., Coffey, M. D., Girke, T., Wang, Z. H., Close, T. J., Roose, M., Yokomi, R. K., Folimonova, S., Vidalakis, G., Rouse, R., Bowman, K. D., and Jin, H. L. 2013. Small RNA profiling reveals phosphorus deficiency as a contributing factor in symptom expression for citrus Huanglongbing disease. Mol. Plant 6:301-310. 